\title{
Co tłumaczy słownik przekładowy? Uwagi na marginesie pracy Dariusza Bralewskiego, Od przekładu do słownika. Korpus równoległy w redakcji słowników tłumaczeniowych, Łask 2012 („Rozumienie - Interpretacja - Przekład”, t. 9), 643 strony (recenzja książki)
}

DOl: http://dx.doi.org/10.12775/RP.2015.020

Książka Dariusza Bralewskiego to jedna z niewielu publikacji, które pokazują zastosowanie korpusu w językoznawstwie kontrastywnym ${ }^{1}$. Starannie dobrany zbiór bitekstów ${ }^{2}$ (tj. oryginałów i ich przekładów, odpowiednio na język polski lub francuski) jest w niej traktowany jako cenne źródło informacji leksykograficznej i ważne uzupełnienie dotychczasowej wiedzy na temat gramatycznych i pragmatycznych różnic między badanymi językami. Omawiany tom zawiera więc obszerne rozważania dotyczące korpusów w pracy leksykografa i tłumacza (rozdział I), tertium comparationis w przekładzie (rozdział II), błędów w przekładzie i ich wpływu na jakość korpusu (rozdział III), idei słownika przekładowego (rozdział IV), ekwiwalencji w przekładzie i w słowniku (rozdział V), wreszcie automatycznego pozyskiwania danych przekładowych z korpusu ${ }^{3}$ (rozdział VI). Całość wieńczy aneks grupujący wybrane

${ }^{1}$ Na gruncie polskim niewielkie przyczynki, za punkt wyjścia przyjmujące głównie dydaktykę przekładu, dali m.in. R. Uzar, Korpusy w nauczaniu tłumaczenia $i$ w pracy tłumacza, [w:] Korpusy w angielsko-polskim językoznawstwie kontrastywnym. Teoria i praktyka, A. Duszak, E. Gajek, U. Okulska (red.), Kraków 2006, s. 156-179, oraz P. Pęzik, NKJP w pracy tłumacza, [w:] Narodowy Korpus Języka Polskiego, A. Przepiórkowski, M. Bańko, R.L. Górski, B. Lewandowska-Tomaszczyk (red.), Warszawa 2012, s. 301-311.

${ }^{2}$ Na zebrany przez autora korpus, który umożliwił tak szeroko zakrojone badania, składają się trzy grupy tekstów: dziewiętnastowieczne teksty literackie, współczesne teksty literackie oraz współczesne teksty publicystyczne i specjalistyczne.

${ }^{3}$ W skrócie można powiedzieć, że Bralewski dąży do stworzenia takiego systemu ekscerpcji danych, który w jak największym zakresie wykonywałby komputer, a praca leksykografa polegałaby na sprawdzeniu zaproponowanych przez program rozwiązań i odrzuceniu tych przypadkowych. Badacz zdaje sobie sprawę, że nie jest to system idealny, ale uważa, że lepiej podjąć ryzyko utraty $30-40 \%$ materiału (przy zastosowanych metodach) niż analizować wszystko „ręcznie" (tzn. czytać ze zrozumieniem teksty korpusu), z czym trudno się nie zgodzić. Zaproponowana przez niego metoda, mimo pewnych braków, i tak daje rezultaty dużo bardziej przydatne w praktyce tłumaczeniowej niż ta stosowana dotychczas w leksykografii dwujęzycznej, a zwłaszcza pozwala na wydobycie odpowiedników rzadkich i nietypowych, szczególnie przydatnych w praktyce tłumaczeniowej. 
hasła $\mathrm{z}$ tworzonego przez autora słownika ${ }^{4}$. Zgodnie ze słowami badacza praca jest przeznaczona dla tłumaczy i leksykografów, teoretyków i praktyków przekładu, lingwistów zajmujących się kontrastywnym badaniem języków polskiego i francuskiego, wreszcie nauczycieli języka francuskiego (s. 10). I rzeczywiście, obfituje ona $\mathrm{w}$ ciekawe obserwacje teoretyczne, jak również stanowi kopalnię przykładów tłumaczeń, często niestandardowych, dyskusyjnych, z komentarzami autora mogącymi wiele wnieść do francusko-polskich badań kontrastywnych.

Oryginalność podejścia Bralewskiego przejawia się nie tylko w tym, że traktuje on korpus nie tyle jako narzędzie, co raczej jako przedmiot badań językoznawczych. Omawianą pracę należy uznać za nowatorską także dlatego, że - w przeciwieństwie do wielu opracowań translatorycznych koncentrujących się na wykazywaniu błędów w istniejących tłumaczeniach - autor z zasady ufa wyborom translatorskim, bardzo rzadko dyskwalifikuje je jako błędne, co wynika $z$ jego koncepcji stworzenia słownika nienormatywnego opartego na korpusie równoległym. W rozdziale trzecim badacz na starannie dobranych przykładach pokazuje, że to, co na pierwszy rzut oka mogłoby się wydawać błędem w tłumaczeniu, wcale nim nie jest, bo może wynikać ze strategii przyjętej przez tłumacza bądź niemożliwości oddania w tekście docelowym pewnych, głównie pragmatycznych, właściwości jednostki przekładowej. Daleki od wydawania sądów normatywnych Bralewski pisze:

decydowanie o tym, co jest błędem tłumaczeniowym, jest bardzo trudne, przede wszystkim dlatego, iż nie dysponujemy jednoznacznymi kryteriami optymalności przekładu, a przy ocenie zwracamy uwagę głównie na semantyczną warstwę tekstu. Oczekujemy, że przekład i oryginał będą mówiły dokładnie to samo, ale z przekładowego punktu widzenia dokładnie nie zawsze oznacza dobrze (s. 151).

Dlatego właśnie w słowniku przekładowym jest miejsce na przykłady tłumaczeń oraz na kwalifikatory, które pomogą rozpoznać stopień ekwiwalencji ${ }^{5}$ obu tekstów (mogą one pokazywać przecięcie semiczne translanda

${ }^{4}$ Do tej pory powstały dwa tomy: D. Bralewski, Francusko-polski słownik (graficznych) odpowiedników przekładowych, t. 1: a - ancien, t. 2: anciennement - azyme, Łask 2013.

${ }^{5}$ Bralewski w rozdziale piątym broni tezy, że ekwiwalencja przekładowa - pojmowana jako relacja podobieństwa, a nie identyczności - jest przechodnia, odwracalna i symetryczna, co pokazuje, porównując przekłady w obu kierunkach (s. 213-218). Za Adamem Bednarkiem powtarza, że o ekwiwalencji można mówić w odniesieniu do tekstu, a nie do leksyki. 
i translatu, ich przynależność do wspólnego pola semantycznego, zachodzące między nimi relacje przyczynowo-skutkowe, a także antonimię, konwersję czy inkluzję, rozdzielność semiczną, wreszcie różnice pragmatyczne i „ekwiwalenty wymuszone frazeologicznie"). Ciekawym pomysłem wydaje się też uwzględnianie $w$ nim ekwiwalentów zerowych, czyli sytuacji braku odpowiednika $\mathrm{w}$ jednym $\mathrm{z}$ języków (z powodów gramatycznych, semantycznych lub pragmatycznych $)^{6}$.

W pracy znajduje się więc bogaty zbiór tekstów oryginalnych i odpowiadających im przekładów, których niewątpliwą zaletę stanowi fakt, że tworzone były w sposób naturalny dla potrzeb użytkowych, nie zaś sztucznie, w celu udowodnienia tez językoznawczych. Dodajmy, iż autor zdaje sobie sprawę $\mathrm{z}$ niereprezentatywności stworzonego przez siebie korpusu, a jednocześnie uważa, że jest ona trudnym do osiągnięcia ideałem. Dlatego właśnie przedkłada działania praktyczne nad teoretyczne.

Walka o reprezentatywność korpusu - pisze Bralewski - nie może być ważniejsza od pracy na korpusach. Inaczej mówiąc, praca z korpusem niereprezentatywnym wydaje się gwarantować mniejszą subiektywność opisu rzeczywistości niż badania zdane wyłącznie na kompetencję językową badacza (s. 40).

Ukoronowaniem prac nad i z korpusem bitekstów jest w koncepcji autora „słownik (prawdziwie) przekładowy”, stawiany przez niego w opozycji do „słownika dwujęzycznego”. Najważniejsze różnice między nimi starałyśmy się zebrać w poniższym zestawieniu.

\begin{tabular}{|l|l|}
\hline \multicolumn{1}{|c|}{ słownik przekładowy } & \multicolumn{1}{c|}{ słownik dwujęzyczny } \\
\hline $\begin{array}{l}\text { opracowywany z perspektywy tłumacza } \\
\text { i przez pryzmat tłumaczeń }\end{array}$ & $\begin{array}{l}\text { opracowywany z perspektywy leksykografa } \\
\text { i przez pryzmat wcześniejszych dzieł leksy- } \\
\text { kograficznych }\end{array}$ \\
\hline oparty na tekstach (oryginale i przekładzie) & $\begin{array}{l}\text { oparty na ciągach graficznych uznawanych } \\
\text { za odpowiedniki międzyjęzykowe, często na } \\
\text { podstawie tradycji lub arbitralnych decyzji } \\
\text { leksykografa }\end{array}$ \\
\hline
\end{tabular}

${ }^{6}$ „Wydaje się, że uświadomienie sobie przymusu opuszczenia jakiegoś elementu tekstu może uchronić tłumacza - szczególnie mniej doświadczonego - od błędu nadtłumaczenia, zwłaszcza że dla niektórych jednostek ekwiwalent zerowy bywa najczęstszym lub bardzo częstym odpowiednikiem tekstowym" (s. 238). 


\begin{tabular}{|l|l|}
\hline \multicolumn{1}{|c|}{ słownik przekładowy } & \multicolumn{1}{|c|}{ słownik dwujęzyczny } \\
\hline $\begin{array}{l}\text { pokazuje relacje zachodzące między teksta- } \\
\text { mi niemożliwe do wydobycia na podstawie } \\
\text { konfrontacji tylko systemów językowych }\end{array}$ & $\begin{array}{l}\text { pokazuje relacje zachodzące między lekse- } \\
\text { mami na poziomie systemu*, a pomija istot- } \\
\text { ne informacje przekładowe, jak np. systema- } \\
\text { tyczne nietłumaczenie pewnych segmentów } \\
\text { czy modyfikacje ortonimiczne }\end{array}$ \\
\hline $\begin{array}{l}\text { pokazuje również „niekanoniczne” oraz } \\
\text { błędne rozwiązania translatorskie }\end{array}$ & $\begin{array}{l}\text { pokazuje wyłącznie odpowiedniki uznawa- } \\
\text { ne za „kanoniczne” }\end{array}$ \\
\hline $\begin{array}{l}\text { po stronie translatu notuje wiele konteksto- } \\
\text { wo warunkowanych bliskoznaczników }\end{array}$ & $\begin{array}{l}\text { jest ubogi w bliskoznaczniki, co skutkuje } \\
\text { niekonsekwencjami w obrébie jednego ha- } \\
\text { sła, kiedy przykłady użyć zawierają odpo- } \\
\text { wiedniki inne niż te podane w części defi- } \\
\text { nicyjnej }\end{array}$ \\
\hline $\begin{array}{l}\text { zawiera nie tylko odpowiedniki, ale również } \\
\text { przykłady oraz kwalifikatory, dzięki którym } \\
\text { czytelnik może zrekonstruować także prag- } \\
\text { matyczne właściwości translatów (skojarze- } \\
\text { nia z nimi związane) }\end{array}$ & $\begin{array}{l}\text { nie zawiera zbyt wielu przykładów, raczej } \\
\text { arbitralnie wybrane odpowiedniki }\end{array}$ \\
\hline $\begin{array}{l}\text { ujawnia pragmatyczne i kulturowe proble- } \\
\text { my przekładu }\end{array}$ & $\begin{array}{l}\text { kulturowe problemy przekładu ujawnia spo- } \\
\text { radycznie w wypadku leksemów, dla których } \\
\text { trudno znaleźć ekwiwalenty systemowe }\end{array}$ \\
\hline $\begin{array}{l}\text { nie jest normatywny, jego głównym zadaniem } \\
\text { jest dokumentowanie procesu przekładu }\end{array}$ & jest w pewnym sensie normatywny \\
\hline
\end{tabular}

Ciekawy i oryginalny projekt Dariusza Bralewskiego może jednak budzić pewne kontrowersje i skłaniać do poważniejszej dyskusji. Pierwsza wątpliwość dotyczy przeznaczenia i potencjalnej grupy odbiorców słownika przekładowego. Sam autor wyobraża go sobie jako źródło wiedzy i pomoc zarówno dla specjalistów, jak i tych, nawet gorzej znających opisywane języki, użytkowników, którzy pragną - na podstawie zaczerpniętych ze słownika wiadomości - generować własne teksty. Założenie to wydaje się jednak mało realistyczne, ponieważ sposób prezentowania haseł wskazuje na problemy dość oczywiste dla profesjonalnego tłumacza, trudne natomiast do zrozumienia dla laika. Bralewski proponuje, by (skoro czasowniki nie muszą być $\mathrm{w}$ tekście docelowym tłumaczone przez formy czasowników, przymiotniki - przymiotników itd.) w artykułach hasłowych po stronie translatu umiesz-

* „Niektóre odpowiedniości tzw. systemowe (formalne) - pisze nie bez racji Bralewski nigdy nie pojawiają się w innych tekstach niż słowniki dwujęzyczne" (s. 13). Krytycznie o słownikach dwujęzycznych wypowiadają się również metaleksykografowie, por. np. R.R.K. Hartmann, Interlingual Lexicography. Selected Essays on Translation Equivalence, Contrastive Linguistics and the Bilingual Dictionary, Tübingen 2007, s. 15-16. 
czać wszystkie możliwe odpowiedniki, które pojawiły się w korpusie. I tak, czasownik accabler otrzymuje obok takich odpowiedników jak przytłaczać, obsypywać, przygnębiać, obciążać również translaty przymiotnikowe (m.in. przytłaczający, zgnębiony, ciężki, ociężały), rzeczownikowe (przygnębienie) czy przysłówkowe (ciężko). Jakkolwiek wszystkie one znajdują potwierdzenie w tekstach, są jednak ich incydentalną, jednostkową właściwością. Doświadczony tłumacz powinien wiedzieć, że niektóre części mowy powstają w wyniku operacji (w rozumieniu Andrzeja Bogusławskiego ${ }^{7}$ ). Notowanie wszystkich możliwych wariantów dostępnych w korpusie może zaś tylko zaciemnić obraz (czasownikowi accabler przypisano na przykład 21 odpowiedników, dających się pogrupować w cztery grupy semantyczne, zob. s. 49). Autor wychodzi wprawdzie z założenia, że

dopiero zamieszczenie jak najliczniejszych, pochodzących z dwutekstów, przykładów użycia proponowanych ekwiwalentów [...] pozwala wybrać odpowiednik najwłaściwszy w danej sytuacji translatorskiej (s. 69),

wydaje się jednak, że mniej doświadczony użytkownik słownika, widząc kilkadziesiąt odpowiedników, najczęściej zapozna się tylko z kilkoma pierwszymi. Takie rozwiązanie jest zatem dość niepraktyczne. Poza tym może wprowadzać w błąd, o czym niech świadczą dwa przykłady: jednym z odpowiedników przymiotnika ardent ma być wyraz taki (przykł. [42] na s. 64), a rzeczownika ami - redaktor (przykł. [81] na s. 99):

[42] [...] en passant devant chaque restaurant, un désir ARDENT de manger lui mouillait la bouche de salive. $\rightarrow$ [...] gdy mijał restaurację, ślina napływała mu do ust, TAKI był głodny.

[81] - Cher AMI! - Son geste bref et éloquent ne laissait pas le moindre doute sur ses intentions. $\leftarrow-$ Panie REDAKTORzE! - Jego krótki i wymowny gest natychmiast zorientował Pawlickiego, o co chodzi.

Użytkownik słownika, niemający czasu na szczegółowe analizy (Bralewski tylko pobieżnie omawia ardent na 12 stronach), może odnieść błędne wrażenie, że ami rzeczywiście znaczy redaktor. Pokazanie wszystkich możliwych odpowiedników („zaktualizowanych znaczeń”, jak pisze autor) znalezionych w tekstach nie jest zaś ani możliwe, ani - co istotniejsze - celowe.

7 Por. A. Bogusławski, Preliminaria gramatyki operacyjnej, „Polonica” 1988, t. XIII, s. 163-223. 
Tu rodzi się kolejny problem, tym razem dotyczący przyjętej w słowniku Bralewskiego jednostki ekwiwalencji. Jak twierdzi autor, jego punkt widzenia „jest perspektywą leksykografa, a jednostką porównania najmniejszy możliwy fragment znaczący - najczęściej słowo graficzne" (s. 12). Jednocześnie ubolewa nad tym, że „mimo znacznej objętości pracy [...] nie poświęcono specjalnego miejsca problemowi jednostki tłumaczeniowej" (s. 15). Zagadnienie to istotnie wydaje się ważne, zwłaszcza w kontekście proponowanych przez autora, odbiegających od tradycyjnych, rozwiązań leksykograficznych. Uważne spojrzenie na cytowane wyżej przykłady [42] i [81] uświadamia nam bowiem, że mamy do czynienia nie tyle $\mathrm{z}$ odpowiedniością ardent - taki i ami - redaktor, lecz raczej z ekwiwalencją przekładową ciągów un désir ardent de manger lui mouillait la bouche de salive - ślina naplywała mu do ust, taki był głodny (ewentualnie, w ujęciu skróconym, un désir ardent de manger - taki był głodny) oraz panie redaktorze! - cher ami! Choć Bralewski podkreśla na każdym kroku zasadność brania pod uwagę szerszego ko(n)tekstu i przekonująco dowodzi konieczności pracy z tekstami, nie zaś z izolowanymi jednostkami języka, w przygotowanym przez niego słowniku przekładowym odnotowane są głównie odpowiedniości na poziomie słów. Rozwiązanie takie wydaje się prowadzić do powstawania par dość mylących dla niewprawnego użytkownika. O ile zresztą odpowiedniość redaktor - ami można by uznać za incydentalną (a więc, naszym zdaniem, niekoniecznie godną odnotowania w słowniku), to problem odpowiednika przymiotnika ardent $\mathrm{w}$ przykładach typu [42] trudno rozstrzygnąć z przyczyn czysto praktycznych. Czy należałoby odnotowywać w słowniku przekładowym odpowiedniości typu un désir ardent de + infinitif - być takim + przymiotnik czy może np. un X ardent (de + infinitif Y) (gdzie X jest nazwą odczucia, rzeczownikiem odnoszącym się do stanów wolitywnych etc.). - być takim $\mathrm{Z}$ (gdzie $\mathrm{Z}$ jest przymiotnikiem oznaczającym stan odpowiadający znaczeniom fr. $\mathrm{X}$ i Y, np. un désir de manger - być głodnym)? Trudno odpowiedzieć na to pytanie, wydaje się jednak, że przyjęte przez autora rozwiązanie jest zbyt uproszczone i może prowadzić do nieporozumień. Problem ten dotyczy zresztą znacznej części cytowanych przez badacza przykładów, por. np. fragment [225] na s. 185:

[225] D’abord, son séide n’a pas cessé de grogner sur mes talons comme un tigre. J'étais AGRAFÉ par une poigne de fer; mon bras en est bleu $\rightarrow$ Najpierw jego totumfacki nieustannie deptał mi po piętach, dysząc jak tygrys. CzuŁem żelazny ucisk na przedramieniu, moja ręka jest cała sina [...]. 
Odpowiednikami przekładowymi są nie tyle izolowane słowa agrafé czułem, co raczej ciągi jétais agrafé (par une poigne de fer) - czułem (żelazny) ucisk. Wyodrębnianie wielosegmentowych odpowiedników stwarza niewątpliwie problem przy automatycznej ekscerpcji danych, co nie zmienia jednak faktu, że zagadnienie to wymaga naszym zdaniem głębszego przemyślenia.

Słownik przekładowy ma też, w założeniu autora, stanowić uzupełnienie (lub alternatywę) dla słowników tradycyjnych, których autorzy, opierając się głównie na dawniejszych opracowaniach leksykograficznych i własnej intuicji językowej, pomijają często ważne odpowiedniości międzyjęzykowe pojawiające się w tekstach tłumaczeń. Bralewski przekonująco pokazuje niekonsekwencję wielu haseł słownikowych, nienotujących wśród odpowiedników danego wyrazu tych jednostek, które następnie pojawiają się w cytowanych jako ilustracja hasła przykładach. Autor omawia m.in. notowane w opracowaniu Mirosławy Słobodskiej ${ }^{8}$ hasło nastolatek:

adolescent $m$ nastolatek; un camp d’adolescents obóz młodzieżowy.

Dlaczego odpowiednikiem wyrazu hasłowego jest tylko nastolatek, ale już nie młodzież, skoro wyrażenie to (przekształcone) znalazło się w ilustracji materiałowej? - pyta nie bez racji Bralewski (s. 157).

Krytyka to z pewnością słuszna, wydaje się jednak, że - mimo odmienności przyjętych założeń i metod badawczych - rezultat pracy autora przedstawiony w słowniku przekładowym nie odbiega (w aż tak znacznym stopniu, jak postuluje badacz) od tego, co ukazane jest w słownikach tradycyjnych. Sam Bralewski, analizując różnorodne odpowiedniki wyrazu ardent, zauważa, iż

to, że za sprawą jednego wyrazu graficznego $\mathrm{z}$ lewej strony korpusu znalazły się razem leksemy o tak różnych znaczeniach systemowych, jak: goracy, ogniowy, blagalny, pełen, zapalczywy, mocny, taki czy weglik, wynika z faktu, iż to kontekst odegrał rolę selektora znaczenia aktualnego [...]. Użycie konkretnego leksemu często wymuszone jest obowiązującymi w języku docelowym naturalnymi sposobami mówienia o rzeczywistości przedstawionej w tekście. Są one w mniejszym lub większym stopniu zleksykalizowane i dlatego tłumacz w zasadzie nie ma swobody podejmowania decyzji. Jeśli po polsku trzeba mówić o 'mocno rozgrzanym węglu', użyjemy przymiotnika rozżarzony, jeśli od paleniska 'rozchodzi się ciepło', powiemy, że bije od niego żar [...] (s. 66-67).

${ }^{8}$ Język francuski na co dzień: francusko-polski, polsko-francuski słownik popularny, Warszawa 1997. 
Różnorodne odpowiedniości międzywyrazowe ujawniają się więc w szerszym kontekście, w związkach często ustalonych i silnie zleksykalizowanych. To właśnie próbują nam chyba przekazać także autorzy słowników tradycyjnych. Mimo że nie notują wśród listy odpowiedników części wyrazów cytowanych następnie w przykładach, co na pierwszy rzut oka można by uznać za dowód niekonsekwencji, pokazują jednak podobne odpowiedniości na poziomie frazeologizmów. Cytowane wyżej hasło adolescent użytkownik języka odczyta więc zapewne w ten sposób: „najbardziej typowym odpowiednikiem rzeczownika adolescent będzie w polszczyźnie rzeczownik nastolatek, ale $\mathrm{w}$ połączeniu $\mathrm{z}$ wyrazem obóz używa się przymiotnika młodzieżowy". Z punktu widzenia przydatności słowników krytykę istniejących opracowań można by więc chyba uznać za zbyt surową. Nie zmienia to jednak faktu, że dzięki wykorzystaniu szerszego korpusu autentycznych tłumaczeń słownik przekładowy prezentuje użytkownikowi znacznie więcej możliwych odpowiedników danego wyrazu.

Do refleksji skłania wreszcie problem podejścia autora do błędu tłumaczeniowego. Jak twierdzi Bralewski, „ekwiwalencja w przekładzie nie jest dana z góry, ale jest przez niego tworzona. Dlatego też nie podejmujemy dyskusji z rzeczywistością tekstową. Naszym zadaniem jest rejestracja, a jedyne prawo, jakie sobie rezerwujemy, to prawo do komentarza" (s. 274) ${ }^{9}$. Postulowane przez leksykografa umieszczanie w słowniku „wszystkich bez wyjątku propozycji tłumaczeniowych" (s. 106) nie wydaje się jednak celowe. Wprawdzie w rozdziale trzecim Bralewski przekonująco pokazuje, że nie wszystkie usterki przekładu są rzeczywistymi błędami, jednak jego zamiar, by w słowniku notować również przekłady błędne i odpowiednio je komentować (za pomocą systemu kwalifikatorów), jest - naszym zdaniem - niefunkcjonalny. Po pierwsze, słownik rozrósłby się do ogromnych rozmiarów, hasła byłyby objętościowo duże, co utrudniłoby korzystanie z nich. Po drugie, jeśli pewne błędy nie występują seriami (jak na przykład te związane $\mathrm{z}$ „fałszywymi przyjaciółmi” tłumacza), przywoływanie ich byłoby znów tylko zatrzymywaniem się nad faktami jednostkowymi. Po trzecie, zamieszczanie błędów i dyskusja (nawet szczątkowa) nad nimi doprowadziłaby do zatarcia różnicy między słownikiem a publikacją dydaktyczną. Po czwarte, użytkownicy słowników szukają w nich jednoznacznych odpowiedzi na nurtujące ich py-

${ }^{9} \mathrm{~W}$ innym miejscu Bralewski pisze: „Odwoływanie się do owocu cudzej pracy powinno zakładać zaufanie do jej wykonawcy. Nie chodzi tu oczywiście o bałwochwalcze uwielbienie, ale o pokorny krytycyzm: łatwo bowiem ustalić, iż dany przekład jest tak zły, że nie nadaje się do wykorzystania w słowniku" (s. 562). 
tania dotyczące „poprawności” danego ekwiwalentu, a nie rozważań na temat tego, jaki nietypowy odpowiednik także mógłby być dopuszczalny w ściśle określonych, specyficznych warunkach. Nie do końca przekonująco brzmi teza leksykografa, że „słownik przekładowy [...] nie powinien być słownikiem normatywnym, jego głównym zadaniem winno być dokumentowanie procesu przekładu” (s. 107). Wydaje się, że nie jest to zadanie słownika, lecz dydaktyki przekładu; to w procesie kształcenia tłumaczy istotne jest pokazywanie błędów, słownik tymczasem postrzegany jest przez większość jego użytkowników jako wyrocznia pokazująca jedyne dobre rozwiązania ${ }^{10}$. Bralewski uważa, że „użytkownik słownika, poinformowany o frekwencji danej odpowiedniości, będzie mógł ocenić powtarzalność zaproponowanego rozwiązania i sam podejmie ostateczną decyzję co do jego przydatności” (s. 152). Nasuwa się tu jednak ważne pytanie o różnicę między funkcją słownika (w tradycyjnym rozumieniu podającego mniej lub bardziej gotowe rozwiązania) z funkcją korpusu (prezentującego - po wydaniu odpowiedniej komendy - w jakiś sposób posortowany, ale jednak wymagający samodzielnej analizy materiał przykładowy).

Wreszcie niektóre podawane przez autora przykłady tłumaczeń „niewiernych”, lecz uzasadnionych mogą budzić wątpliwości. W części poświęconej błędom autor przywołuje następujące zdanie:

[155] Moi, je me marierai avec un Avocat ou guelqu'un de ce genre. $\leftarrow$ Wyjdę za LEKARZA albo kogoś takiego.

Z kontekstu wynika, że bohaterka chce poślubić majętnego mężczyznę o wysokiej pozycji społecznej, tak by móc wieść wygodne życie. W polskim oryginale pojawia się lekarz, tłumacz uznał zaś, że lepiej te skojarzenia odda adwokat. Jest to jednak decyzja na tyle jednostkowa (i na pewno niejednoznaczna z punktu widzenia ekwiwalencji przekładu, a być może po prostu niepotrzebna), że umieszczanie jej w słowniku wydaje się nadużyciem. Choć zdaniem autora „słownik odpowiedniości przekładowych powinien notować takie pary, gdyż pokazują one usytuowanie kulturowe jednostek leksykalnych" (s. 137; podkr. D.B.), wydaje nam się, że konotacje kulturowe związane z zawodem lekarza i adwokata są w obu kulturach podobne, a notowanie tego odpowiednika nie służy pokazaniu ważnej różnicy pragmatycznej między badanymi językami.

${ }^{10}$ Por. H. Béjoint, Tradition and Innovation in Modern English Dictionaries, Oxford 1994, s. 115 . 
Przedstawione tu uwagi nie zmieniają faktu, że opracowanie Dariusza Bralewskiego wypełnia ważną lukę we wciąż mało rozwiniętej dziedzinie badań kontrastywnych nad językiem polskim i francuskim. Należy zwrócić uwagę na erudycję autora - jego znajomość starszych i nowszych koncepcji leksykograficznych, semantycznych, translatorycznych pozwala wierzyć, że wybory dokonane przez niego są przemyślane. Godna pochwały jest też jego pokora wobec pracy tłumaczy. Niezwykle cenne dla badań kontrastywnych są omawiane przez niego przykłady, a strona graficzna książki (kolory ułatwiające śledzenie wywodów autora) jest imponująca ${ }^{11}$. Prezentowane tu obserwacje polemiczne stanowią raczej dowód na to, że omawiana praca, bardzo erudycyjna, nowatorska metodologicznie i interesująca pod względem treści, prowokuje do dyskusji na temat spraw ważnych: roli korpusu w badaniach językoznawczych, przeznaczenia i kształtu słowników, sposobu wykorzystania przekładu w pracy leksykograficznej czy też możliwości komputerowej obróbki korpusu równoległego.

\author{
Emilia Kubicka \\ Aleksandra Walkiewicz \\ (Uniwersytet Mikołaja Kopernika w Toruniu)
}

${ }^{11}$ Należy jednak wspomnieć o niezbyt starannej redakcji książki. Chodzi tu o drobne niekonsekwencje w odsyłaczach tekstowych i błędy edytorskie w zapisie bibliograficznym, lecz przede wszystkim o dość kontrintuicyjną i niezgodną z normami określonymi dla języka polskiego interpunkcję, która utrudnia podążanie za myślami autora.

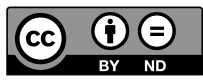

